\title{
Criminal activity and deforestation in Latin America
}

Laura Bolton

Institute of Development Studies

8 December 2020

\section{Question}

What is the evidence on criminal deforestation activity in Latin America (particularly, but not exclusively the Amazon)?

What lessons have been learned in combatting criminal deforestation activity?

\section{Contents}

1. Summary

2. Introduction

3. Criminal involvement in deforestation

4. Surveillance

5. Bribery, corruption, and fraud

6. National systems and policies

7. Violence

8. Involving indigenous communities in combatting deforestation

9. International agreements and action

10. References

The K4D helpdesk service provides brief summaries of current research, evidence, and lessons learned. Helpdesk reports are not rigorous or systematic reviews; they are intended to provide an introduction to the most important evidence related to a research question. They draw on a rapid desk-based review of published literature and consultation with subject specialists. 


\section{Summary}

This review focuses on Brazil as representative of the overwhelming majority of literature on criminal activity in relation to deforestation in the Amazon. 64 percent of the Amazon basin is in Brazil. Peru holds the second largest proportion at only 10 percent. Illegal deforestation occurs largely through criminal networks as they have the capacity for coordination, processing, selling, and the deployment of armed men to protect operations. It is estimated to be five to ten times more profitable than legal operations (Nelleman, 2012). Large networks have the capacity required for investment in equipment and workers. It is estimated that a small proportion of properties are responsible for the majority of illegal deforestation (Rajão et al., 2020).

Illegal logging can be conducted in a number of ways including forgery of permits, logging outside of allowances, laundering illegal timber, and mixing legal with illegal timber during transportation or in sawmills.

Monitoring and law enforcement are essential for reducing deforestation. Estimates suggest that almost half of illegal deforestation goes undetected. Loggers use tactics such as cutting only the most valuable timber to open small clearings that are difficult to detect, cutting timber out slowly, and operating when satellite views are obscured (at night or in the rainy season). The System for Real-time Detection of Deforestation (DETER) is the main environmental monitoring tool in the Amazon but it is limited in technical capacity for measuring small clearings. DETER-B is able to identify smaller areas but has a slower response time where timeliness is very important. Satellite systems need to revisit cleared areas to monitor forest regeneration.

Bribery, corruption and fraud are deeply ingrained in deforestation. Networks may bribe geoprocessing experts, police and public officials. Members of the criminal groups may become council members, mayors, and state representatives. Land titles are fabricated and trading documentation fraudulent.

National systems for registry and monitoring are the most advanced in the region but have limitations. The online rural property registry system for example, is based on unverified self-declared information. There is scope for better integrating different systems. Permits for timber and forest products are easy to falsify and circumvent. Estimates using data from these systems include: up to $\mathbf{8 4}$ percent of deforestation is illegal, 45 percent of registered properties are non-compliant with the Forest Code, 48 percent of slaughtered cattle are associated with illegal deforestation, 20 percent of soy exported to the EU is from illegally deforested land, and more than half of cattle slaughtered are unregistered.

Legal enforcement for compliance of environmental law is weak. Fines can be appealed indefinitely or simply go uncollected. Increased capacity for fine collection is needed with adequate funding and training for human resources. One policy found to be particularly successful was a resolution from the Brazilian Bank in 2008 which meant those with unpaid fines could not access finance for their businesses. This was more effective than fines alone which can be repeatedly appealed or go unpaid without consequence. Land regularisation needs to be promoted to stop land grabbing. Governance measures vary with election cycles and there is a tendency to relax environmental regulations prior to major elections. 
Violence and threats are common with 300 deaths reported to have occurred due to land use conflicts in the last five years. To prevent agency enforcement there has been bridges burned, fuel truck helicopters destroyed, vehicles set on fire, and trees felled over roads. There is systematic failure to investigate and prosecute threats and experienced violence. There is potential discrimination against indigenous groups, and criminal organisations may hold political power. Brazil does have a Program to Protect Defenders of Human Rights, Journalists, and Environmentalists which is of some benefit but needs to be improved.

Indigenous people and local communities have an important role to play in identifying logging which is avoiding satellite detection in the Brazilian Amazon. Where there is lack of resources and staffing for official enforcement agencies indigenous patrol groups may be effective and should be supported with equipment and training.

It was beyond the scope of this report to detail the international certification schemes and programmes which have evolved to reduce illegal logging. These schemes include voluntary trade agreements such as the EU Forest Law Enforcement, Governance and Trade (FLEGT) Voluntary Partnership Agreements (VPAs), or Forest Stewardship Council (FSC) certification (Nellemann, 2012). They have been useful in bringing stakeholders together and generating incentives for legal exports and more sustainable forestry.

Trade agreements to prevent purchasers buying soy and cattle from illegally deforested areas are subject to laundering and leakage. Importers must make increased efforts to ensure that timber, cattle, meat, or agricultural products purchased in Brazil did not originate in illegally deforested or illegally occupied areas in the Amazon. Increased transparency is required in global supply chains with better labelling.

International investment is another important area of influence with both national and international institutions having a role to play. An assessment of Dutch financial institutions found the majority of banks, over half of insurance companies, and all pension funds to have some connection with illegal deforestation. International investors have a role to play in holding Amazonian countries to account.

The International Consortium on Combating Wildlife Crime ${ }^{1}$ (ICCWC), a collaboration of five intergovernmental organisations to support wildlife law enforcement exists as a coordinated support mechanism for addressing money laundering and law enforcement.

Based on experience in Brazil, a number of lessons for combatting illegal deforestation and related activities emerge:

- Surveillance technology could be improved. Indigenous communities should be involved and supported in deforestation surveillance.

- The will and capacity for law enforcement in Brazil is weak and needs to be transformed. Human resource investment is a priority.

- Systems could be tightened and more integrated to reduce corruption and fraudulent behaviour.

${ }^{1}$ https://cites.org/eng/prog/iccwc_new.php Accessed 7.12.20 
- International agreements (both trade and otherwise) can support enforcement, accountability, and transparency.

- Greater attention should be paid to the role financial institutions in funding criminal networks.

- Consumer information should be improved on both financial institutions and products associated with illegal deforestation (beef and soy) so that ethical decisions can be made.

\section{Introduction}

The rapid evidence search for this review produced a vast majority of literature of relevance to the question on the Brazilian Amazon. Table 1 shows that 64 percent of the Amazon basin lies within Brazil. The majority of the scope of this report was taken up with presenting the body of work on Brazil and constitutes the remainder of the report is information on Brazil. Further resources are required to investigate these issues for other countries within the Amazon and in other forested areas in the world. It would be worth investigating how deforestation is addressed in countries with different governance.

See: Table 1. Land area in countries of the Amazon basin, https://globalforestatlas.yale.edu/region/amazon Accessed 30.11.20

The general trend since 2012 has been an increase in the forest clearing rate in the Brazilian Amazon (Carvalho et al., 2019). Estimates from Brazil's National Institute for Space Research suggest forest clearing between August 2019 to July 2020 to have increased by 28 percent compared with the same time period the previous year (Escobar, 2020). Between 2005 and 2012 there had been a decline. Fearnside (2012) cautions against attributing this trend to control measures as the decline correlates with fall in commodity prices.

One of the global concerns for deforestation is the impact on climate change. Estimates in 2004 found forest loss to have contributed to around 70 percent of Brazils greenhouse gas emissions (Assunção \& Gandour, 2019).

A Climate Policy Initiative paper highlights that forest protection is not just important for environmental protection but also important for Brazil's international reputation as the country builds its position in global markets (Assunção \& Gandour, 2019). Environmental protection also has economic implications as agricultural production is dependent on biophysical factors such as the preservation of water resources which is linked to vegetation and ecosystem conservation.

The change in political leadership in Brazil in 2018 has caused concern for environmental goals. The current president is unsupportive of environmental protection and illegal deforestation is thought to have worsened as criminals believe their activities are more likely to be overlooked (Acebes et al., 2019). "Crime groups involved in illegal deforestation have taken President Bolsonaro's statements and policies weakening environmental law enforcement as a green light to destroy the forest and attack forest defenders, several officials told Human Rights Watch" (p131-132).

"In many cases, suitable technologies and systems already exist to better control adherence to the terms of deforestation agreements and legislation, and what is lacking is political will to make full use of these tools." (Carvalho et al., 2019, p126). 


\section{Criminal involvement in deforestation}

Nelleman (2012) estimates illegal timber trade to be five to ten times more profitable than legal operations. Crime and corruption are deeply ingrained (Assunção \& Gandour, 2019). Illegal deforestation occurs largely through criminal networks as the large-scale extraction process requires logistical capacity for coordination, processing, selling, and in the deployment of armed men to protect operations (Acebes et al., 2019). Large networks have the capital to buy heavy equipment and hire workers. The ipê is the most valuable tree and fetches between US $\$ 500$ $\$ 1,500$ per trunk. Once the valuable wood has been removed undetected, the networks cut and set fire to the remaining vegetation opening land for other uses such as cattle rearing (60 percent) and crop farming (6 percent) (Acebes et al., 2019).

Rajão et al (2020) find most of Brazil's agricultural output to be unconnected to deforestation and that only " $2 \%$ of properties in the Amazon and Cerrado are responsible for $62 \%$ of all potentially illegal deforestation and that roughly $20 \%$ of soy exports and at least $17 \%$ of beef exports from both biomes to the EU may be contaminated with illegal deforestation" (p246).

Nellemann (2012) lists more than $\mathbf{3 0}$ ways of conducting illegal logging, laundering, and selling illegal logs. These include forging logging permits, bribing to obtain logging permits, logging outside of allowances, hacking government websites to obtain transport permits for higher volumes, laundering illegal timber, and mixing legal timber during transport or in mills. Laundering operations are becoming increasingly advanced and difficult to detect. Many illegal operations involve bribing forest officials, police, military, and sometimes village heads.

Mining is also connected to deforestation in the Brazilian Amazon but is less prominent in the literature. Illegal mining involves criminal activities similar to logging (Perazzoni, 2018). Activities include fraud in acquiring permits or extraction without a permit, using authorisations for one area to legalise extraction from illegal areas, falsifying documentation with regard to quantity allowances, and corruption of National Department of Mineral Production.

\section{Surveillance}

Monitoring is essential for reducing deforestation (along with law enforcement) (Assunção \& Gandour, 2019). Estimates between 2008 and 2013 suggest that only 55 percent of illegal deforestation was detected and that technological instruments are insufficient to capture data in time to act (Schmitt, 2015).

To evade surveillance loggers increasingly use tactics such as cutting only the most valuable timber to open small clearings and leaving vegetation so clearance is difficult to detect on satellite images. These small clearings accounted for one quarter of deforestation in Brazil in 2002 rising to more than a half in 2012 (Assunção \& Gandour, 2019). Other tactics are to build camps hidden under trees and bring cut timber out slowly rather than accumulating large quantities in sawmills. Perpetrators also may operate at night or in the rainy season when cloud cover obscures the view of the satellite (Boekhout van Solinge, 2018).

A study of the Southern Amazonas Mesoregion used geointelligence techniques for comparing multitemporal satellite sensor images and official data on deforestation and identified a number of inconsistencies (Perazzoni, 2020). These included between transport times and 
prices reported, volumetric information which did not match forest inventories, exploitation outside of authorised limits, and exploitation both before licensing was obtained and after licensing had expired.

Satellite imaging monitoring recent changes in forest cover was developed by the National Institute for Space Research (Inpe), known as the System for Real-time Detection of Deforestation (DETER) (Assunção \& Gandour, 2019). It is the main environmental monitoring tool in the Amazon. Daily images are compared and changes are identified with a georeferenced alert which is passed on to the Brazilian Institute for the Environment and Renewable Natural Resources (IBAMA). It is limited in technical capacity and cannot detect forest loss in areas covering less than 25 hectares. Small-scale clearings have increased since. DETER-B was developed which has the advantage of identifying small areas but has a slower time response.

\section{Recommendations}

Improvements in technology to detect small-scale clearing in real-time are needed (Acebes et al., 2019; Carvalho et al., 2019). The current satellite system does not revisit cleared areas so secondary vegetation is not monitored which makes regeneration vulnerable (Acebes et al., 2019). An estimated 17 million hectares of secondary vegetation was identified in the Amazon in 2014 equivalent to nearly a quarter of all deforested land suggesting a large amount of cleared land is abandoned. Forest regeneration is in the Forest Code and the goals set out in the Paris Agreement. Technology such as electronic cattle-identification may also be considered to improve tracking of cattle reared on different pieces of land (Carvalho et al., 2019).

\section{Bribery, corruption, and fraud}

The criminal networks may keep the deforested lands and fabricate titles with the names of frontmen which requires geoprocessing experts to forge surveys (Acebes et al., 2019). Police and public officials may be bribed. Members of the criminal groups may become council members, mayors, and state representatives. Logs get passed as legal with fraudulent documentation for example, overestimating the volume of timber in a legally logged area and adding to that stock. Cattle raised illegally "escape controls by either selling it to clandestine slaughterhouses, passing it for cattle raised in legal ranches, or selling it to cattle ranchers who specialize in cattle fattening and who in turn sell it to legal slaughterhouses" (Acebes et al., 2019, p36).

Scope for falsifying required documentation (Carvalho et al., 2019) and evidence on the extent of these activities is described in the next section.

\section{National systems and policies}

\section{Systems}

Brazil has an online environmental registry system Cadastro Ambiental Rural (CAR) which, along with its Forest Code, monitors compliance of rural properties. A number of areas are established areas of permanent protection (APP). According to Rajão et al (2020) these systems make Brazil stand apart from other countries. However, there are issues with CAR as it is based on unverified self-declared information (Carvalho et al., 2019). 
The CAR registry system should be used along with mapping and monitoring programmes, and animal tracking systems for a national and public monitoring system to enforce environmental compliance (Rajão et al., 2020). Rather than costly private certification systems that lack transparency and include only specific farms, CAR needs to be integrated with the Animal Transit Permit, the legally required hygiene check (Carvalho et al., 2019). Measures are needed to prevent documents being falsified.

Timber and forest products are controlled through a computerised system which issues a 'Forest Origin Document' (FOD) after approval of a 'Sustainable Forest Management Plan' (Carvalho et al., 2019). The FOD is a compulsory licence to control the transport of forest product which can be circumvented in a number of ways. Permit holders can overestimate the amount of timber extracted from approved areas to cover extraction from illegal areas. Fake timber merchants are created which simulate legal movement of timber. Logging licences can overestimate the commercial value of timber within that area and so cover for timber extracted from illegal areas. Surveys show discrepancies between species approved for extraction and volumes present (Brancalion et al., 2018). Sustainable Forest Management plans have loopholes which allow the complete harvesting of an area in the first year of a 30-year plan meant for staggered harvesting (Carvalho et al., 2019).

The database for mining activity, Cadastro Mineiro, records authorised locations, types of activities, and the valid dates of permits (Perazzoni, 2018). A complementary geographic information system identifies the location and dimensions of the estate authorised. The system has been useful in its abilities to verify permits and whether physical limits are being respected.

\section{Evidence}

A study links illegal deforestation on individual properties to their agricultural production and exports to Europe (Rajão et al., 2020). A large sample of CAR properties found $\mathbf{4 5}$ percent to be non-compliant either with the Forest Code for protecting APPs or failing to conserve minimum legal-reserve areas. 15 percent of the sample were deforested since 2008, with $\mathbf{8 4}$ percent of the deforestations in the Amazon illegal. 50 percent of properties growing soy were deforested illegally although there is a soy moratorium that prevents the trading of soy grown on deforested lands in this biome. 18-22 percent of the soy exported to the EU is potentially contaminated. Around 48 percent of cattle slaughtered may have been reared at some point in illegal deforested land.

The Terms of Adjustment of Conduct (TAC) agreement commits signatories to refuse cattle from suppliers using illegally deforested properties, those who were under embargo, or who did not meet environmental and social criteria. The G4 agreement excludes cattle from any deforested property, whether the deforestation had been legal or illegal. Klinger et al (2017) uses cattle vaccination data to assess agreement compliance by slaughterhouses in the state of Para between 2010 and 2014. The authors note "both the cattle agreements and the soybean moratorium focused on leveraging commodity purchasers' influences over farm or ranch-level producers" (p35). More than half of a sample of cattle from Novo Progresso were vaccinated in protected areas or were not registered. Qualitative research finds an inability or lack of will for ranchers to track cattle before their sale to a slaughterhouse. Animals were often raised on areas out of compliance and then sold to an intermediary. The researchers 
found inaccurate registration and weak tracing mechanisms. Ranchers also have the option to sell to non-signatories.

Gibbs et al. (2016) analyse slaughterhouse purchases before and after zero-deforestation cattle agreements signed by major meatpacking companies. They found that slaughterhouses responded positively by avoiding purchasing from properties with deforestation. And that supplying properties had reduced deforestation.

\section{Policy and law enforcement}

Brazil's legal system is known to be slow and allows for successive appeals so that those with money for legal protection can easily avoid prosecution (Carvalho et al., 2019). Assessment of sanctions in Mato Grosso State finds they play an important role in slowing deforestation but measures to improve the collection of fines are urgently needed (Sousa, 2016). Fine imposition was found to be negatively correlated with deforestation and embargoes were highly effective. A study assessing field-based forest law enforcement found they had not been universally effective but highly cost-effective on average (Börner et al., 2015). Another study estimates that only 24 percent of those detected as not complying with the Forest Code receive fines (Schmitt, 2015). And due to staffing and administrative problems, of those receiving fines between only between 0.2 and 5 percent of fines are paid. Enforcing fines would produce large amounts of funds which could be spent on environmental conservation and restoration (Carvalho et al., 2019).

In 2008, there was a policy change ${ }^{2}$ which meant that those with unpaid environmental fines could not access subsidised financing from the government (Carvalho et al., 2019). This had a stronger impact than the fines themselves which can be appealed repeatedly and are often not followed through (Fearnside, 2017). In the same year, a "blacklist" system was initiated to penalise states with high illegal deforestation making it difficult for them to obtain deforestation licenses (Carvalho et al., 2019).

Fearnside $(2017, \mathrm{p} 8)$ notes "The strength of governance measures varies with election cycles, and there is a tendency to relax enforcement of environmental regulations prior to major elections, producing a significant relation between deforestation rates and elections".

\section{Land law}

Brazil's Constitution recognises the rights of Indigenous peoples to the lands have traditionally occupied and which they live on permanently (Acebes et al., 2019). The federal government is entrusted with the obligation to protect indigenous lands.

A new law passed in $\mathbf{2 0 1 7}$ granted amnesty to those who illegally occupied land and allows land grabbers to purchase public lands below market prices. Brito et al (2019) assess the impact of this law on land grabbing finding loss of government revenue ranging between 5 to 8 billion USD in the short-term. Long-term estimates show a risk of between 
1.1 and 1.6 million hectares being deforested as a result, equivalent to $4.5-6.5$ megatonnes of $\mathrm{CO}_{2}$ emissions.

Probst et al (2020) analyse a large-scale land-titling programme called Terra Legal finding evidence that small and medium land holders actually increased deforestation as land is more profitable for cattle and crops.

\section{Recommendations}

Federal and state governments are responsible for creating (or maintaining the existence of) effective police operations specialised in environmental crimes (Acebes et al., 2019). This requires allocation of adequate funds for human resources. Police backup is needed for inspectors. Nellemann (2012) recommends increasing national law enforcement capacities through an INTERPOL based training scheme and support in forming national taskforces.

The Minister of Justice should convene all federal and state law enforcement authorities with meaningful input from civil society organisations and indigenous peoples (Acebes et al., 2019). There needs to be federal tracking of cases of violence and federalisation of cases of violence that go without investigation. A group of federal (and state) prosecutors specialised in rural violence and deforestation should be supported and enforcement systems integrated to avoid producers from one state selling in another (Carvalho et al., 2019). All federal services need more staff and resources (Acebes et al., 2019; Carvalho et al., 2019). All prosecutors failing to uphold their duty should be held accountable with impartial investigations into their dealings with criminal networks.

The administration must give messages of support and stop verbal attacks on NGOs. They have the power to maintain, expand and protect the Amazon rainforest (Acebes et al., 2019).

The Ministry of Environment must guarantee inspector autonomy to impose fines and reestablish the Department of Forests and Combatting Deforestation. They need to enrol additional human resources to speed up administrative processes (Acebes et al., 2019).

Issuing of permits should be centralised nationally to avoid trade being moved from illegal to legal regions (Nellemann, 2012).

Complementary strategies must be developed to combat illegal deforestation in agrarian reform settlements and undesignated public lands (Acebes et al., 2019). Since 2010, an estimated two-thirds of the Amazon's deforested area lies within public lands, primarily in agrarian reform settlements (30\%) and in undesignated areas (25\%). Combating illegal deforestation should therefore be aligned with the development and implementation of other public policies, especially those that promote land regularisation. This is particularly relevant to the Brazilian Amazon, due to its long history of irregular occupation. Effective and correct implementation of the CAR is needed to avoid irregular occupation and land grabbing (Carvalho et al., 2019).

Land-tenure establishment based on deforestation must not continue (Fearnside, 2018). Land speculation causes deforestation that has no benefits for the country.

Tax fraud investigations should focus on plantations and sawmills either laundering timber or mis-reporting volumes (Nellemann, 2012). 


\section{Violence}

Between 2010 and 2020 an estimated 300 people have died in conflicts over land use and resources in the Brazilian Amazonian states according to the Pastoral Land Commission (Acebes et al., 2019). Reports from community forest patrollers highlights danger and threats. Violence and intimidation are also used by land grabbers and loggers to deter officials from upholding the law. A Human Rights Watch report (Acebes et al., 2019) documents the killing of 28 people, the attempted killing of 4 , and more than 40 death threats though interviews with many stakeholders. The majority of the incidences recorded were after 2015 . Violence against agency enforcement in Brazil include burning of bridges, destruction of a fuel truck for helicopters, setting vehicles on fire and felling trees to obstruct roads. These acts are rarely prosecuted.

There is systematic failure to investigate and prosecute threats and experienced violence (Acebes et al., 2019). The authorities claim that the remote locations of these incidents make them difficult to investigate and that there are not resources to travel to these areas, including human resources and all-terrain vehicles. Reports from the Human Rights Watch interviews suggests there may be some discrimination against indigenous groups or that local police may be involved with the illegal activities. Criminal organisations hold political power. Brazil has a Program to Protect Defenders of Human Rights, Journalists, and Environmentalists which had 410 people receiving protection, of which 70 percent are defenders of indigenous rights and the environment. The protection, albeit perceived to be weak, does provide some recognition of the problem and accountability for continued actions.

\section{Fires}

Between January and August in 2019 satellites detected 46,000 locations in the Amazon with active forest fires, more than twice the amount from the same period the previous year (Acebes et al., 2019). In August, smoke from Brazil and neighbouring countries reached the city of São Paulo enough to cover this in darkness. It is believed that fires may be contributing to respiratory diseases. And gases and particles released are harmful particularly to children.

"The attorney general said there is evidence the fires were the result of an "orchestrated action" prepared in advance. The Pará state government said criminal groups had planned to deforest, burn, and raise cattle in a 200 square kilometre area in a conservation reserve." (Acebes et al., 2019, p142).

\section{Involving indigenous communities in combatting deforestation}

Indigenous people and local communities have an important role to play in identifying logging which is avoiding satellite detection in the Brazilian Amazon (Acebes et al., 2019). It is not possible to employ enforcement officers to cover such a large area and local communities are less likely to be corrupted. Illegal deforestation has been found to be 250 percent less likely in indigenous areas possibly due to local community enforcement (Ding et al., 2016). 
In the state of Maranhão, Brazil, lack of resources and staffing are identified for enforcement agencies to carry out their job (Acebes et al., 2019). Here, indigenous peoples have formed patrols known as 'Forest Guardians', groups of around 15 who identify sites and provide authorities with names. In the Caru Indigenous Territory members of a women's group are learning to use drones to detect deforestation. Some of them also go on patrol with men. There are examples of successful collaboration between these groups and the police. There are also examples where the authorities fail to, or are unable to, respond. The patrols sometimes detain loggers or their vehicles themselves which is legal though burning the vehicles is not. They are aware that patrolling is a risk but feel they have no choice. Other indigenous peoples carry out similar activities though the case of the Forest Guardians is a particularly well organised example.

"Brazil's duty to protect forest defenders and others from acts of violence and intimidation by criminal groups involved in illegal logging - and bring perpetrators of these acts to justice - is part of its obligations under international human rights law." (Acebes et al., 2019, p??). The relevant law is the International Covenant on Civil and Political Rights (ICCPR). ${ }^{3}$

Property rights can help to secure support from indigenous communities. Baragwanath \& Bayi (2020) test satellite data from between 1982 and 2016 to assess the causal effect between indigenous property rights and reduced deforestation. They find significantly less deforestation inside a territory with full property rights than in areas right outside the border.

\section{Recommendations}

Forest defenders should be funded, equipped and trained. The Federal Programme to Protect Human Rights Defenders in Brazil needs improved procedures and staff training for risk analysis (Acebes et al., 2019). Protection plans for forest defenders should include: electricity (solar panels or other means) for remote internet communication, security cameras in homes, transportation expenses so that defenders are less isolated, and funding for legal representation so they may pursue complaints against assailants. Forest defenders need to be ensured confidentiality with information they share.

The Escazú regional agreement on Access to Information, Public Participation and Justice in Environmental Matters in Latin America and the Caribbean adopted needs to be ratified so that states guarantee an enabling environment for the protection of forest defenders (Acebes et al., 2019).

\section{International agreements and action}

\section{Laws and agreements}

It was beyond the scope of this report to detail all of the certification schemes and programmes which have evolved to reduce illegal logging. These schemes include voluntary trade agreements such as the EU Forest Law Enforcement, Governance and Trade (FLEGT)

\footnotetext{
${ }^{3}$ https://www.ohchr.org/en/professionalinterest/pages/ccpr.aspx Accessed 4.12.20
} 
Voluntary Partnership Agreements (VPAs), or Forest Stewardship Council (FSC) certification (Nellemann, 2012). They have been useful in bringing stakeholders together and generating incentives for legal exports and more sustainable forestry.

The Action Plan for the Prevention and Control of Deforestation in the Legal Amazon ${ }^{4}$ (PPCDAm), launched in 2004, is one of the most important regional agreements (Nelleman, 2012). It aims to reduce deforestation rates continuously alongside transition towards a sustainable development model in the region.

\section{International trade}

The Brazilian government created agreements so that goods produced comply with forest protection including the Terms of Adjustment of Conduct (TAC) for meatpacking companies in 2009 and the Soy Moratorium in 2006 (Lujan, 2018). The Soy Moratorium aimed at stopping the main soy purchasers from buying beans produced in illegally deforested areas. However, laundering can occur when soy is commercialised as if it were produced in legal areas or in the names of people who serve as fronts for illegal activities (Carvalho et al., 2019). And leakage can occur for example when farmers grow soy in legal areas that were being used to graze cattle and then deforest other areas to move the cattle to.

The TAC aimed to bar the sale of cattle that had been reared on or produced in illegal land (Carvalho et al., 2019). Ranchers find ways around the agreement by, for example, registering only the parts of their land that are legally deforested or selling cattle to those with legal land who act as middlemen. Only half of meatpackers have signed the agreement and there is little market pressure, particularly from the increasingly important Chinese market. And there was no punishment for those that produced cattle illegal areas.

The European Union are critical of the Brazilian government response to illegal deforestation which is hampering trade agreement decisions (Rajão et al., 2020). The Brazilian Government state that international conservation laws are upheld.

\section{Recommendations}

Importers must make increased efforts to ensure that timber, cattle, meat, or agricultural products purchased in Brazil did not originate in illegally deforested or illegally occupied areas in the Amazon. Companies need to disclose their procedures and the origins of their products (Acebes et al, 2019).

Increased transparency is required in global supply chains with better labelling (Carvalho et al., 2019). Initiatives such as Transparency for Sustainable Economics (Trase) $)^{5}$ are working on getting information on supply chain transparency out in the public domain and should be

\footnotetext{
${ }^{4}$ http://redd.mma.gov.br/en/legal-and-public-policyframework/ppcdam\#: :text=The\%20Action\%20Plan\%20for\%20the,development\%20model\%20in\%20the\%20regi on Accessed 7.12.20
}

\footnotetext{
${ }^{5}$ https://trase.earth/ accessed 2.12.20
} 
supported. Trase use publicly available data to show linking between commodity exports and agricultural conditions.

Nellemann (2012) recommends an international rating system of companies to reduce investor attractiveness to those using illegal practices.

\section{International action}

Ethical investment is an important area for international influence. Large investments are required to enable illegal timber laundering which come from Asia, EU and the US including investments through pension funds (Nellemann, 2012). Both domestic and international financial institutions have a role to play, including banks, insurance companies and pension funds. Van Gelder and Kuepper (2020) assessed the policies and actions of Dutch financial institutions for association with deforestation-risk companies. They found 6 out of 7 banks, 5 out of 9 insurance companies and 10 out of 10 pension funds to have relationships with these companies. Four of the banks provided loans to the deforestation-risk companies. Four financial institutions demonstrated steps taken to prevent involvement in deforestation. All companies should be rated on the likelihood of their involvement in illegal logging to discourage stock markets and investors from funding them (Nellemann, 2012). Financial institutions need to commit to zero tolerance, set clear and strict policy criteria, be transparent, communicate expectations, screen and exclude offenders, and continually monitor (Van Gelder and Kuepper, 2020).

Norway have withdrawn some funding for actions to prevent deforestation which was conditional on deforestation rates improving and have threatened to withdraw more if rates do not improve (Carvalho et al., 2019).

Ecosystem services such as maintaining biodiversity, recycling water, and storing carbon to support global warming reduction need to be assigned value payments internationally (Carvalho et al., 2019). These costs of deforestation are higher than profits to be made however, there are difficulties in calculating such values.

Nellemann (2012) suggests that investigation of tax fraud, corruption and laundering should be prioritised and supported by national task forces working with INTERPOL. The International Consortium on Combating Wildlife Crime $^{6}$ (ICCWC) is a collaboration of five intergovernmental organisations ${ }^{7}$ to support wild life law enforcement. It provides a substantial commitment to sharing and coordinating international efforts. It represents the chain of customs, police and justice. It also addresses anti-money laundering. "The cost of implementing an effective international law enforcement scheme and training capacity to substantially reduce the emissions from illegal logging is estimated to be approximately US $\$ 20$ 30 million dollars annually" (Nellemann, 2012, p8).

\footnotetext{
${ }^{6}$ https://cites.org/eng/prog/iccwc_new.php Accessed 7.12.20

${ }^{7}$ CITES Secretariat, INTERPOL, the United Nations Office on Drugs and Crime (UNODC), the World Bank and the World Customs organization (WCO)
} 


\section{References}

Acebes, C.M., Wilkinson, D., \& Téllez-Chávez, L. (2019). Rainforest Mafias. How Violence and Impunity Fuel Deforestation in Brazil's Amazon. Human Rights Watch. https://www.hrw.org/sites/default/files/report_pdf/brazil0919_web.pdf

Assunção, J., \& Gandour, C. (2019). Combating illegal deforestation strengthening command and control is fundamental. Climate Policy Initiative. https://www.climatepolicyinitiative.org/wpcontent/uploads/2019/04/white-paper-Combating-Illegal-Deforestation-Strengthening-Command-andControl-Is-Fundamental.pdf

Baragwanath, K., \& Bayi, E. (2020). Collective property rights reduce deforestation in the Brazilian Amazon. Proceedings of the National Academy of Sciences, 117(34), 20495-20502. https://www.pnas.org/content/117/34/20495.short

Boekhout van Solinge, T. (2015). Deforestation in the Brazilian Amazon. In Shroder, J. F. (ed) Biological and environmental hazards, risks, and disasters. Elsevier. https://www.cabdirect.org/cabdirect/abstract/20163238319

Boekhout van Solinge, T. (2018). GPS-supported, community-based forest crime prevention in the Brazilian Amazon. Oxford Martin Programme on the Illegal Wildlife Trade.

https://www.illegalwildlifetrade.net/2018/11/22/gps-supported-community-based-forest-crimeprevention-in-the-brazilian-amazon/

Boekhout van Solinge, T. (2020). Deforestation in the Brazilian Amazon and Cerrado. In Funding destruction of the Amazon and the Cerrado-savannah. A Fair Finance Guide Netherlands case study on deforestation risks in soy and beef supply chains. Eerlijke Geldwijzer. https://fairfinanceguide.org/media/496089/funding-destruction-of-amazon-cerrado.pdf

Börner, J., Kis-Katos, K., Hargrave, J., \& König, K. (2015). Post-crackdown effectiveness of fieldbased forest law enforcement in the Brazilian Amazon. PLoS One, 10(4), e0121544.

https://journals.plos.org/plosone/article?id=10.1371/journal. pone. 0121544

Brancalion, P. H., de Almeida, D. R., Vidal, E., Molin, P. G., Sontag, V. E., Souza, S. E., \& Schulze, M. D. (2018). Fake legal logging in the Brazilian Amazon. Science advances, 4(8), eaat1192.

https://advances.sciencemag.org/content/4/8/eaat1192?fbclid=IwAR3m9LQI3RIsMUF2BuQm_QCI3J A6KPXpn647jHBzWLNAEMoluxTOERfTGXs\&utm_source=TrendMD\&utm_medium=cpc\&utm_campa ign=TrendMD_1

Brito, B., Barreto, P., Brandão Jr, A., Baima, S., \& Gomes, P. H. (2019). Stimulus for land grabbing and deforestation in the Brazilian Amazon. Environmental Research Letters, 14(6), 064018. https://iopscience.iop.org/article/10.1088/1748-9326/ab1e24/meta

Carvalho, W. D., Mustin, K., Hilário, R. R., Vasconcelos, I. M., Eilers, V., \& Fearnside, P. M. (2019). Deforestation control in the Brazilian Amazon: A conservation struggle being lost as agreements and regulations are subverted and bypassed. Perspectives in Ecology and Conservation, 17(3), 122-130. https://www.sciencedirect.com/science/article/pii/S2530064418301263\#bib0050

Ding, H., Veit, P., Blackman, A., Gray, E., Reytar, K., Altamirano, J. C., \& Hodgdon, B. (2016). Climate benefits, tenure costs: the economic case for securing indigenous land rights in the 
amazon. World Resources Institute, Washington DC, USA. https://www.wri.org/publication/climatebenefits-tenure-costs

Escobar, H. (2020). Illegal deforestation in Brazil soars amid climate of impunity. Science https://doi. org/10.1126/science. abe1725. https://www.sciencemag.org/news/2020/08/illegal-deforestation-brazilsoars-amid-climate-impunity

Fearnside, P. (2017). Deforestation of the Brazilian Amazon. In Oxford research encyclopedia of environmental science.

https://oxfordre.com/environmentalscience/environmentalscience/view/10.1093/acrefore/9780199389 414.001.0001/acrefore-9780199389414-e-102

Gibbs, H. K., Munger, J., L'Roe, J., Barreto, P., Pereira, R., Christie, M., Amaral, T., \& Walker, N. F. (2016). Did ranchers and slaughterhouses respond to zero-deforestation agreements in the Brazilian Amazon? Conservation Letters, 9(1), 32-42.

https://conbio.onlinelibrary.wiley.com/doi/full/10.1111/conl.12175

Lujan, B. (2018). A Comparison of Supply Chain Tracking Tools for Tropical Forest Commodities in Brazil. Environmental Defense Fund.

https://www.edf.org/sites/default/files/documents/Supply_Chain_Tracking_Tools.pdf

Nellemann, C. (2012). Green carbon, black trade: illegal logging, tax fraud and laundering in the world's tropical forests. Green carbon, black trade: illegal logging, tax fraud and laundering in the world's tropical forests. https://gridarendal-website-

live.s3.amazonaws.com/production/documents/:s_document/609/original/GRIDPublication.pdf?16057 84279

Perazzoni, F. (2018). Amazonia, organized crime and illegal deforestation: best practices for the protection of the Brazilian Amazon. In The 21st Century Fight for the Amazon (pp. 21-55).

Palgrave Macmillan, Cham.

https://link.springer.com/chapter/10.1007/978-3-319-56552-1_2

Probst, B., BenYishay, A., Kontoleon, A., \& dos Reis, T. N. (2020). Impacts of a large-scale titling initiative on deforestation in the Brazilian Amazon. Nature Sustainability, 1-8.

https://www.nature.com/articles/s41893-020-0537-2

Rajão, R., Soares-Filho, B., Nunes, F., Börner, J., Machado, L., Assis, D., Oliveira, A., Pinto, L., Ribeiro, V., Rausch, L. and Gibbs, H., 2020. The rotten apples of Brazil's

agribusiness. Science, 369(6501), pp.246-248.

https://science.sciencemag.org/content/369/6501/246.summary

Schmitt, J. (2015). Crime sem castigo: a efetividade da fiscalização ambiental para o controle do desmatamento ilegal na Amazônia. https://repositorio.unb.br/handle/10482/19914

Sousa, P. Q. (2016). Decreasing deforestation in the Southern Brazilian Amazon-The role of administrative sanctions in Mato Grosso State. Forests, 7(3), 66. https://www.mdpi.com/19994907/7/3/66

Van Gelder, J.W. \& Kuepper, B. (2020). Funding destruction of the Amazon and the Cerradosavannah A Fair Finance Guide Netherlands case study on deforestation risks in soy 
and beef supply chains. Eerlijke Geldwijzer. https://fairfinanceguide.org/media/496089/fundingdestruction-of-amazon-cerrado.pdf

\section{Acknowledgements}

- Tim Boekhout van Solinge, Independent consultant and criminologist. Expert in forest/wildlife crime, illegal drug markets, and rule of law. Registered in the Consultants Roster of the United Nations. Director, Forest Forces (). Research fellow, Department of criminology, Erasmus University Rotterdam

- Thomas Rudel, Professor Emeritus, Rutgers

\section{Suggested citation}

Bolton, L. (2020). Criminal activity and deforestation in Latin America. K4D Helpdesk Report 918. Brighton, UK: Institute of Development Studies. DOI: 10.19088/K4D.2021.003

\section{About this report}

This report is based on nine days of desk-based research. The K4D research helpdesk provides rapid syntheses of a selection of recent relevant literature and international expert thinking in response to specific questions relating to international development. For any enquiries, contact helpdesk@k4d.info.

K4D services are provided by a consortium of leading organisations working in international development, led by the Institute of Development Studies (IDS), with Education Development Trust, Itad, University of Leeds Nuffield Centre for International Health and Development, Liverpool School of Tropical Medicine (LSTM), University of Birmingham International Development Department (IDD) and the University of Manchester Humanitarian and Conflict Response Institute (HCRI).

This report was prepared for the UK Government's Foreign, Commonwealth and Development Office (FCDO) and its partners in support of pro-poor programmes. It is licensed for non-commercial purposes only. Except where otherwise stated, it is licensed for non-commercial purposes under the terms of the Open Government Licence v3.0. K4D cannot be held responsible for errors, omissions or any consequences arising from the use of information contained in this report. Any views and opinions expressed do not necessarily reflect those of FCDO, K4D or any other contributing organisation.

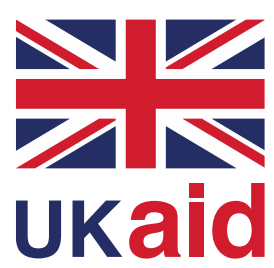

from the British people

(C) Crown copyright 2020. 